\title{
Health-Related Quality of Life, Satisfaction with Care, and Cosmetic Results in Relation to Treatment among Patients with Keratinocyte Cancer in the Head and Neck Area: Results from the PROFILES Registry
}

\author{
Lindy Paulina Johanna Arts $^{a}$ Rick Waalboer-Spuij ${ }^{b, c}$ Kees-Peter de Roos ${ }^{d}$ \\ Monique R.T.M. Thissen ${ }^{\mathrm{e}-\mathrm{g}}$ Luc J. Scheijmans ${ }^{\mathrm{h}}$ Mieke J. Aarts $^{\mathrm{a}}$ \\ Simone Oerlemans ${ }^{a}$ Marnix L.M. Lybeert ${ }^{i}$ Marieke W.J. Louwman ${ }^{a}$ \\ a Department of Research and Development, Netherlands Comprehensive Cancer Organisation, Utrecht, The \\ Netherlands; ${ }^{b}$ Department of Dermatology, Elisabeth-TweeSteden Hospital, Tilburg, The Netherlands; ${ }^{\mathrm{c}}$ Department \\ of Dermatology, Erasmus MC, Rotterdam, The Netherlands; ${ }^{\mathrm{d}}$ Department of Dermatology, DermaPark, Uden, The \\ Netherlands; ${ }^{e}$ Department of Dermatology, Catharina Hospital, Eindhoven, The Netherlands; ${ }^{f}$ Department of \\ Dermatology, Maastricht University Medical Centre, Maastricht, The Netherlands; ${ }^{9} \mathrm{GROW}$, School for Oncology and \\ Developmental Biology, Maastricht University, Maastricht, The Netherlands; ${ }^{\text {h}}$ Department of Radiation Oncology, \\ Dr. Bernard Verbeeten Institute, Tilburg, The Netherlands; 'Department of Radiation Oncology, Catharina Hospital, \\ Eindhoven, The Netherlands
}

\begin{abstract}
Background: Little is known about the impact of keratinocyte cancer $(\mathrm{KC})$ and its treatment on health-related quality of life (HRQoL). Objectives: The objectives of the present study were (1) to evaluate HRQoL among patients with $\mathrm{KC}$ in a population-based setting and compare this with an ageend sex-matched normative population and (2) to compare HRQoL, satisfaction with care, and cosmetic results among patients who underwent conventional excision, Mohs' micrographic surgery, or radiotherapy. Method: A random sample of 347 patients diagnosed with cutaneous basal cell or squamous cell carcinoma in the head and neck area between January 1, 2010, and December 31, 2014, were selected from the Netherlands Cancer Registry (NCR) and were invited to complete a questionnaire on $\mathrm{HRQ}$ L, satisfaction with care, and cosmetic results. Data were collected within Patient-Reported Outcomes Following Initial Treatment and
\end{abstract}

Long-term Evaluation of Survivorship (PROFILES). Outcomes were compared to an age- and sex-matched normative population. Results: Two hundred fifteen patients with KC returned a completed questionnaire (62\% response). Patients with KC reported better global quality of life (79.6 vs. $73.3, p<0.01)$ and less pain $(p<0.01)$ compared to the normative population. No statistically significant differences in HRQoL, satisfaction with care, and cosmetic results were found between patients with KC who underwent conventional excision, Mohs' micrographic surgery, or radiotherapy. Conclusions: The impact of $\mathrm{KC}$ and its treatment seems relatively low and more positive than negative as patients reported better HRQoL compared to an age- and sex-matched normative population, probably due to adaptation. No statistically significant differences between treatment types were found concerning $\mathrm{HRQ} \mathrm{L}$, patient satisfaction, and cosmetic results. This information could be used by healthcare

$\begin{array}{ll}\text { karger@karger.com } & \text { (c) } 2019 \text { The Author(s) } \\ \text { Published by S. Karger AG, Basel } & \text { Karger } \\ \text { Thw.karger.com/drm } & \text { This article is licensed under the Creative Commons Attribution- } \\ \text { NonCommercial-NoDerivatives 4.0 International License (CC BY- } \\ \text { NC-ND) (http://www.karger.com/Services/OpenAccessLicense). } \\ \text { Usage and distribution for commercial purposes as well as any dis- } \\ \text { tribution of modified material requires written permission. }\end{array}$

Lindy Paulina Johanna Arts

Department of Research and Development

Netherlands Comprehensive Cancer Organisation

PO Box 19079, NL-3501 DB Utrecht (The Netherlands)

E-Mail l.arts@iknl.nl 
professionals involved in KC care to improve patients' knowledge about different aspects of the disease as patient's preference is an important factor for treatment choice.

(C) 2019 The Author(s)

Published by S. Karger AG, Basel

\section{Introduction}

Keratinocyte cancer (KC) is the most common cancer in the Western world $[1,2]$. Basal cell carcinomas (BCCs) and squamous cell carcinomas (SCCs) account for, respectively, 80 and $20 \%$ of cases of KC [2-4]. These cancers are called $\mathrm{KC}$ because they share lineage with keratinocytes and histologically resemble epidermal keratinocytes [3]. Keratinocytes are vulnerable to damage from sun exposure and therefore KCs usually develop on sun-exposed areas, especially the head and neck [5-8]. BCCs are slow-growing cancers that are nearly always asymptomatic, while SCCs may grow faster and may induce tenderness or pain, but are also mostly asymptomatic [3]. However, SCCs are more aggressive cancers with a tendency to metastasis, especially the larger ones located on the lips and ears [9].

$\mathrm{KC}$ is typically treated with surgical excision. However, less invasive options exist, such as radiotherapy, cryotherapy, or topical therapy $[3,4,10]$. Choice of treatment depends on various factors, both clinical and personal. Important clinical factors are aggressiveness of the cancer, size and localization of the lesion, and especially for BCC, histological subtype $[4,11]$. In addition, elderly patients and those with comorbid conditions are less suitable for surgical excision and are more likely to receive a less invasive treatment option. Furthermore, cosmetic aspects and patients' preferences may also have an impact on the choice of treatment, since treatment of KC can cause substantial facial cosmetic and functional disturbances [11]. Previous research showed that most prevalent concerns of patients with $\mathrm{KC}$ include worries about tumor recurrence, as well as the potential size and conspicuousness of the scar [12].

Patient-reported outcomes and health-related quality of life (HRQoL) are increasingly important outcomes in daily patient care $[8,13,14]$. HRQoL refers to an individual's physical, psychological, and social well-being, which may be affected by disease and treatment [15]. Since patients with KC are likely to develop multiple cancers during a lifetime, $\mathrm{KC}$ and its treatment may be associated with impaired HRQoL [16]. Despite the high incidence rates of $\mathrm{KC}$ and the importance of incorporating patient values into evidence-based medicine, little is known about the impact of specific treatment options for KC on HRQoL $[13,17]$. In addition, attention on the perspectives of patients with $\mathrm{KC}$ has been increasing over the past 2 decades, since previous research focused mainly on patients with melanoma $[14,18]$. Satisfaction with care is also a part of the patient-reported outcomes and more applicable to diseases with multiple treatment options, such as KC [19]. As patients with KC have strongly expressed the need for a shared decision-making process $[20,21]$, in which they are actively engaged and value detailed information regarding their disease and treatment options, healthcare professionals who are working with patients with KC need to understand their psychosocial concerns and needs in order to offer appropriate care services [22].

The aims of the present study were (1) to evaluate HRQoL among patients with $\mathrm{KC}$ in a population-based setting and compare this with an age- end sex-matched normative population and (2) to compare HRQoL, satisfaction with care, and cosmetic results among patients who underwent conventional excision, Mohs' micrographic surgery, or radiotherapy.

\section{Materials and Methods}

For further details, online supplementary Material (see www. karger.com/doi/10.1159/000502033) [14, 23-29] (Fig. 1).

\section{Results}

\section{Patient Characteristics}

A total of 215 patients with KC returned a completed questionnaire (62\% response). Respondents were younger compared to nonrespondents $(p<0.001)$ and had a more recent diagnosis of KC ( $p=0.004$; Table 1$)$. No differences between responding and nonresponding patients were found according to type of cancer or localization.

The mean age at completion of the questionnaire was 71.3 years, with a mean time since diagnosis of 3.3 years. Most patients were diagnosed with BCC (81\%) and almost half of all patients reported they have had more than one skin cancer. Medium educational level was most common (60\%). Comorbid conditions were reported by $75 \%$ of patients. In the normative population, mean age at questionnaire completion was 69.3 years, with a comorbidity percentage of $70 \%$. In our sample, $49 \%$ of patients with $\mathrm{KC}$ underwent conventional excision, 26\% 
Fig. 1. Flowchart of Materials and Meth-

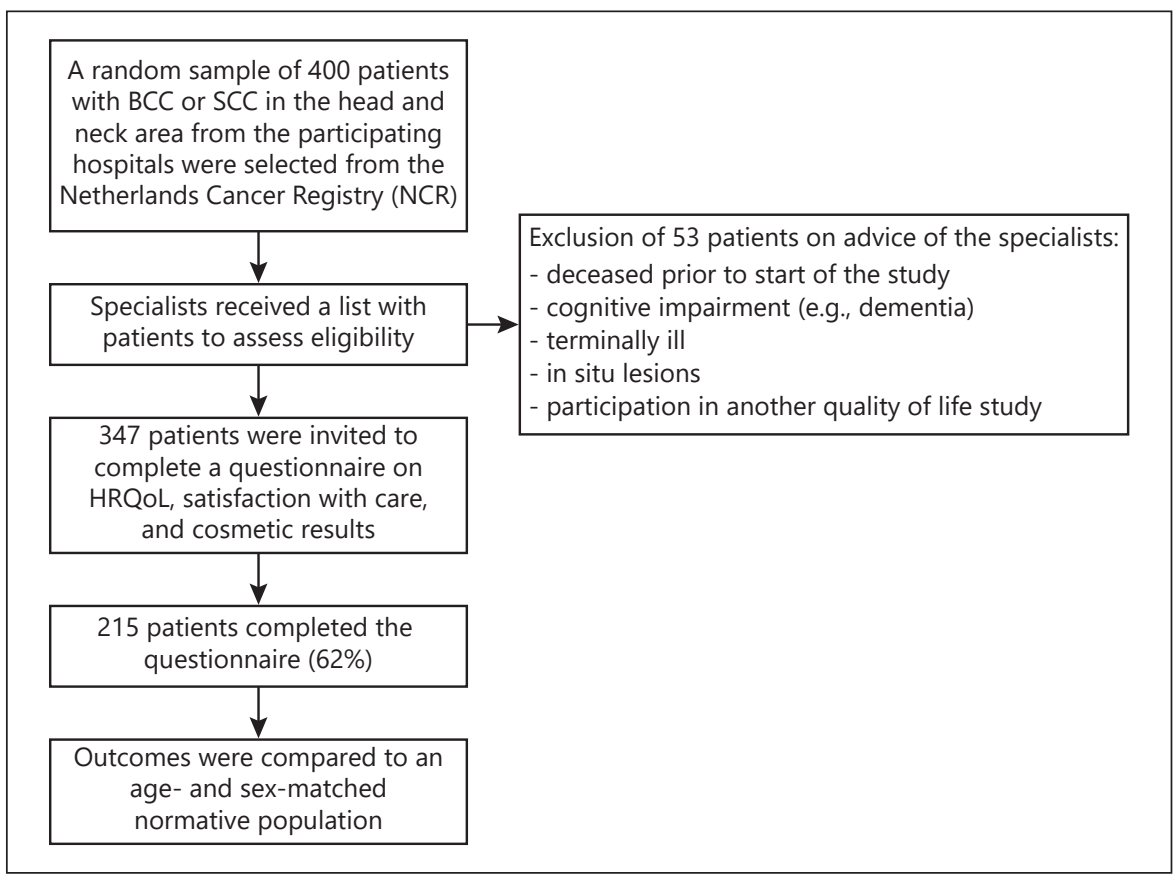
ods. Data collection process.

Table 1. Sociodemographic and clinical characteristics of responding and nonresponding patients with keratinocyte cancer, and an age- and sex-matched normative population

\begin{tabular}{|c|c|c|c|}
\hline & $\begin{array}{l}\text { Respondents } \\
(n=215)\end{array}$ & $\begin{array}{l}\text { Nonrespondents } \\
(n=130)\end{array}$ & $\begin{array}{l}\text { Normative population } \\
(n=255)\end{array}$ \\
\hline \multicolumn{4}{|l|}{ Gender } \\
\hline Male & $116(54)$ & $66(51)$ & $137(54)$ \\
\hline Female & $99(46)$ & $64(49)$ & $118(46)$ \\
\hline Age at time of survey, years & $71.3 \pm 11.9$ & $76.6 \pm 14.1^{*}$ & $69.3 \pm 12.8$ \\
\hline$<50$ & $14(7)$ & $6(5)$ & $16(6)$ \\
\hline $50-59$ & $24(11)$ & $13(10)$ & $27(11)$ \\
\hline $60-69$ & $38(18)$ & $13(10)$ & $45(18)$ \\
\hline $70-79$ & $89(41)$ & $31(24)$ & $105(41)$ \\
\hline $80+$ & $50(23)$ & $67(52)$ & $62(24)$ \\
\hline Years since diagnosis, years & $3.3 \pm 1.4$ & $3.7 \pm 1.5^{*}$ & \\
\hline \multicolumn{4}{|l|}{ Educational level $^{1}$} \\
\hline Low & $34(17)$ & & $95(37)^{*}$ \\
\hline Medium & $120(60)$ & & $62(24)^{*}$ \\
\hline High & $47(23)$ & & $98(38)^{*}$ \\
\hline \multicolumn{4}{|l|}{ Partner } \\
\hline Yes & $66(31)$ & & $83(33)$ \\
\hline No & $149(69)$ & & $172(67)$ \\
\hline Self-reported comorbidities, $n$ & $1.5 \pm 1.5$ & & $1.4 \pm 1.3$ \\
\hline \multicolumn{4}{|c|}{ Most frequent comorbid condition } \\
\hline Hypertension & $64(32)$ & & $92(36)$ \\
\hline Arthritis & $65(32)$ & & $81(32)$ \\
\hline
\end{tabular}

Values are $n(\%)$ or mean \pm SD. $* p<0.05$, significantly different from respondents.

${ }^{1}$ Educational level: low, none/primary school; medium, lower general secondary education/vocational training; high, pre-university education/high level vocational training/university. 
Table 2. Sociodemographic and clinical characteristics of questionnaire respondents who were treated with radiotherapy, conventional excision, or Mohs' micrographic surgery

\begin{tabular}{|c|c|c|c|c|}
\hline & $\begin{array}{l}\text { Conventional } \\
\text { excision } \\
(n=106)\end{array}$ & $\begin{array}{l}\text { Mohs' } \\
\text { micrographic } \\
\text { surgery }(n=19)\end{array}$ & $\begin{array}{l}\text { Radiotherapy } \\
(n=55)\end{array}$ & $p$ value \\
\hline \multicolumn{4}{|l|}{ Sex } & \multirow[t]{4}{*}{0.34} \\
\hline Male & $54(51)$ & $8(42)$ & $33(60)$ & \\
\hline Female & $52(49)$ & $11(58)$ & $22(40)$ & \\
\hline Age at time of survey, years & $68.2 \pm 11.9$ & $67.4 \pm 13.2$ & $75.9 \pm 9.7$ & \\
\hline$<50$ & $9(8)$ & $4(21)$ & $0(0)$ & \multirow[t]{5}{*}{$\leq 0.001$} \\
\hline $50-59$ & $17(16)$ & $1(5)$ & $4(7)$ & \\
\hline $60-69$ & $24(23)$ & $4(21)$ & $6(11)$ & \\
\hline $70-79$ & $39(37)$ & $6(32)$ & $28(51)$ & \\
\hline $80+$ & $17(16)$ & $4(21)$ & $17(31)$ & \\
\hline \multicolumn{4}{|l|}{ Education level $^{1}$} & \multirow[t]{4}{*}{0.37} \\
\hline Low & $14(14)$ & $1(5)$ & $10(20)$ & \\
\hline Medium & $59(60)$ & $11(58)$ & $32(63)$ & \\
\hline High & $26(26)$ & $7(37)$ & $9(18)$ & \\
\hline Partner (yes) & $77(73)$ & $17(89)$ & $36(65)$ & 0.13 \\
\hline \multicolumn{4}{|l|}{ Type of cancer } & \multirow[t]{4}{*}{0.30} \\
\hline BCC & $86(81)$ & $18(95)$ & $48(87)$ & \\
\hline SCC & $15(14)$ & $1(5)$ & $7(12)$ & \\
\hline Unknown & $5(5)$ & $0(0)$ & $0(0)$ & \\
\hline \multicolumn{4}{|l|}{ Skin cancer } & \multirow[t]{3}{*}{0.04} \\
\hline One skin cancer & $44(42)$ & $9(50)$ & $33(63)$ & \\
\hline Multiple skin cancers & $60(58)$ & $9(50)$ & $19(37)$ & \\
\hline \multicolumn{4}{|l|}{ Localization } & \multirow{7}{*}{$\leq 0.001$} \\
\hline Forehead & $16(15)$ & $1(5)$ & $4(7)$ & \\
\hline Scalp & $23(22)$ & $1(5)$ & $3(5)$ & \\
\hline Nose & $26(25)$ & $6(32)$ & $33(60)$ & \\
\hline Ear & $9(8)$ & $3(16)$ & $6(11)$ & \\
\hline Lip & $3(3)$ & $3(16)$ & $2(4)$ & \\
\hline Other parts of head and neck & $29(28)$ & $5(26)$ & $7(13)$ & \\
\hline Comorbidities, $n$ & $1.2 \pm 1.2$ & $1.4 \pm 1.7$ & $1.6 \pm 1.2$ & 0.22 \\
\hline \multicolumn{5}{|c|}{ Most frequent comorbid condition } \\
\hline Hypertension & $21(21)$ & $8(42)$ & $20(41)$ & 0.02 \\
\hline Arthritis & $26(26)$ & $6(32)$ & $16(33)$ & 0.67 \\
\hline
\end{tabular}

had radiotherapy, and Mohs' micrographic surgery was received by $9 \%$ of patients with $\mathrm{KC}$. The remaining patients received a variety of treatments, such as photodynamic therapy, cryotherapy, or topical chemotherapy. This group, however, was too small to be further outlined. Patients who received radiotherapy were significantly older (75.9 years) than patients with KC who underwent conventional excision or Mohs' micrographic surgery (68.2 and 67.4 years, respectively, $p<0.001$ ). In addition, patients who received radiotherapy had more often cancer located on the nose $(60 \%)$ compared to pa- tients treated with conventional excision or Mohs' micrographic surgery ( 25 and $32 \%$, respectively, $p<0.001$; Table 2).

\section{Comparison between Patients with Multiple Skin}

\section{Cancers and One Skin Cancer}

Patients with multiple skin cancers were less satisfied with the cosmetic results compared to patients with one skin cancer (8.3 vs. $7.7, p<0.01$; Fig. 2 ) and were more concerned about their appearance $(0.18$ vs. $0.32, p=0.04)$. No significant differences were found on HRQoL, as 


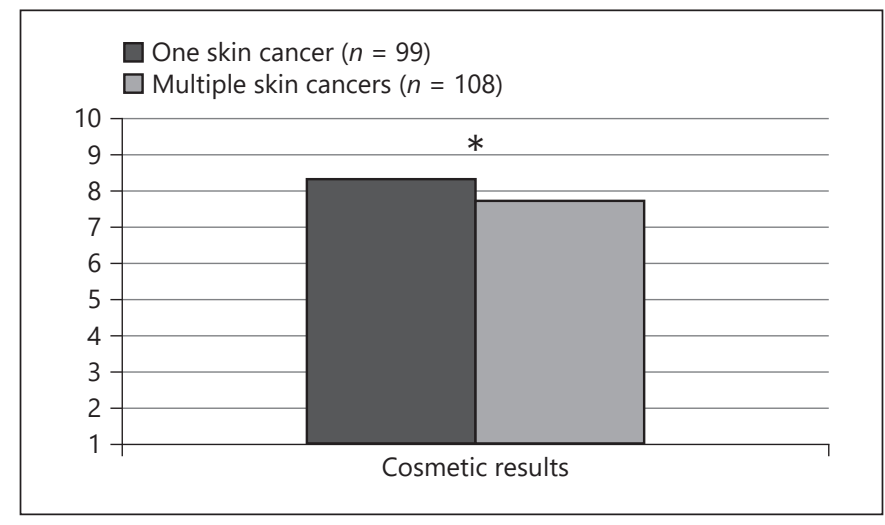

Fig. 2. Differences in cosmetic results between patients who have had one skin cancer $(n=99)$ and patients who have had multiple skin cancers $(n=108) .{ }^{*} p<0.001$.

measured with the European Organization for Research and Treatment of Cancer Quality of Life Questionnaire (EORTC QLQ-C30) and the Basal and Squamous Cell Carcinoma Quality of Life Questionnaire (BaSQoL), between patients with one or multiple skin cancers (all $p>$ 0.05). No differences between patients with infiltrative and noninfiltrative BCC were found in HRQoL scores, general satisfaction with care, and cosmetic results (all $p>0.05)$.

\section{Comparison between Patients with KC and an}

Age- and Sex-Matched Normative Population

No statistically significant differences were observed between patients with $\mathrm{KC}$ and an age- and sex-matched normative population on physical, emotional, cognitive, social, and role functioning (EORTC QLQ-C30; all $p>$ $0.05)$. However, patients with KC reported statistically significant better scores on global quality of life (79.6 vs. $73.3, p<0.01)$ and they reported less pain $(p<0.01)$ compared to a normative population (Fig. $3 \mathrm{a}, \mathrm{b}$ ). These represented small clinically important differences. Other symptoms were comparable $(p>0.05)$.

\section{Comparison between Treatment Groups}

No differences in global quality of life, functioning scores (both EORTC QLQ-C30) or BaSQoL mean scores were found among patients treated with conventional excision, Mohs' micrographic surgery, and radiotherapy (all $p>0.05$; Fig. 4a, b; Table 3 ).

Patients with $\mathrm{KC}$ who underwent radiotherapy were more satisfied with the cosmetic results than patients who underwent conventional excision or Mohs' micrographic surgery ( 8.5 vs. 7.8 and 7.9 , respectively), but this differ-

HRQoL among Patients with $\mathrm{KC}$ in the Head and Neck Area ence was neither statistically significant $(p=0.06)$ nor clinically relevant. Patients who underwent radiotherapy reported better scores for hospital comfort/cleanness (72.1 vs. $62.9, p=0.03)$ compared to patients treated with conventional excision. No other statistically significant differences were found between treatment groups. In all treatment groups, approximately half of the patients rated their general satisfaction with care as "very good" or "excellent".

\section{Discussion/Conclusion}

In this study, patients with $\mathrm{KC}$ reported better global quality of life and less pain compared to an age- and sexmatched normative population. Similar results have previously been observed among patients with other types of cancer [30,31] and among patients with melanoma [32]. A possible explanation is that patients score better because they adapt to the new situation of having a skin cancer diagnosis, assessing their quality of life better than before the diagnosis, the so-called response shift [33].

Although different treatment options may lead to different HRQoL scores, we found similar scores on functioning and global quality of life among patients with $\mathrm{KC}$ who underwent conventional excision, Mohs' micrographic surgery, or radiotherapy. This is in line with research among patients with $\mathrm{KC}$ that showed similar HRQoL after excision and Mohs' micrographic surgery [13]. It was expected that patients who underwent radiotherapy might experience their treatment as more severe, as they need to visit the hospital several days in a row for therapy. Irradiation can also result in complaints about "burning" of the skin $[34,35]$. We found that patients who underwent radiotherapy were more satisfied with the cosmetic results; however, this was not statistically relevant. The mean time since diagnosis was $>3$ years, so it might be that complaints about burning of the skin are not relevant anymore after a few years, while scars as a result of conventional excision or Mohs' micrographic surgery might remain more visible, especially when patients have had multiple skin cancers. It is likely that adverse aspects of different treatment options have a greater impact on HRQoL when patients are closer to diagnosis [13]. In this study, we included only patients with KC who were diagnosed at least 1 year before questionnaire completion. More complaints might be expected when patients are closer to treatment.

Patients who had multiple skin cancers reported lower cosmetic results and more concerns about their appear- 


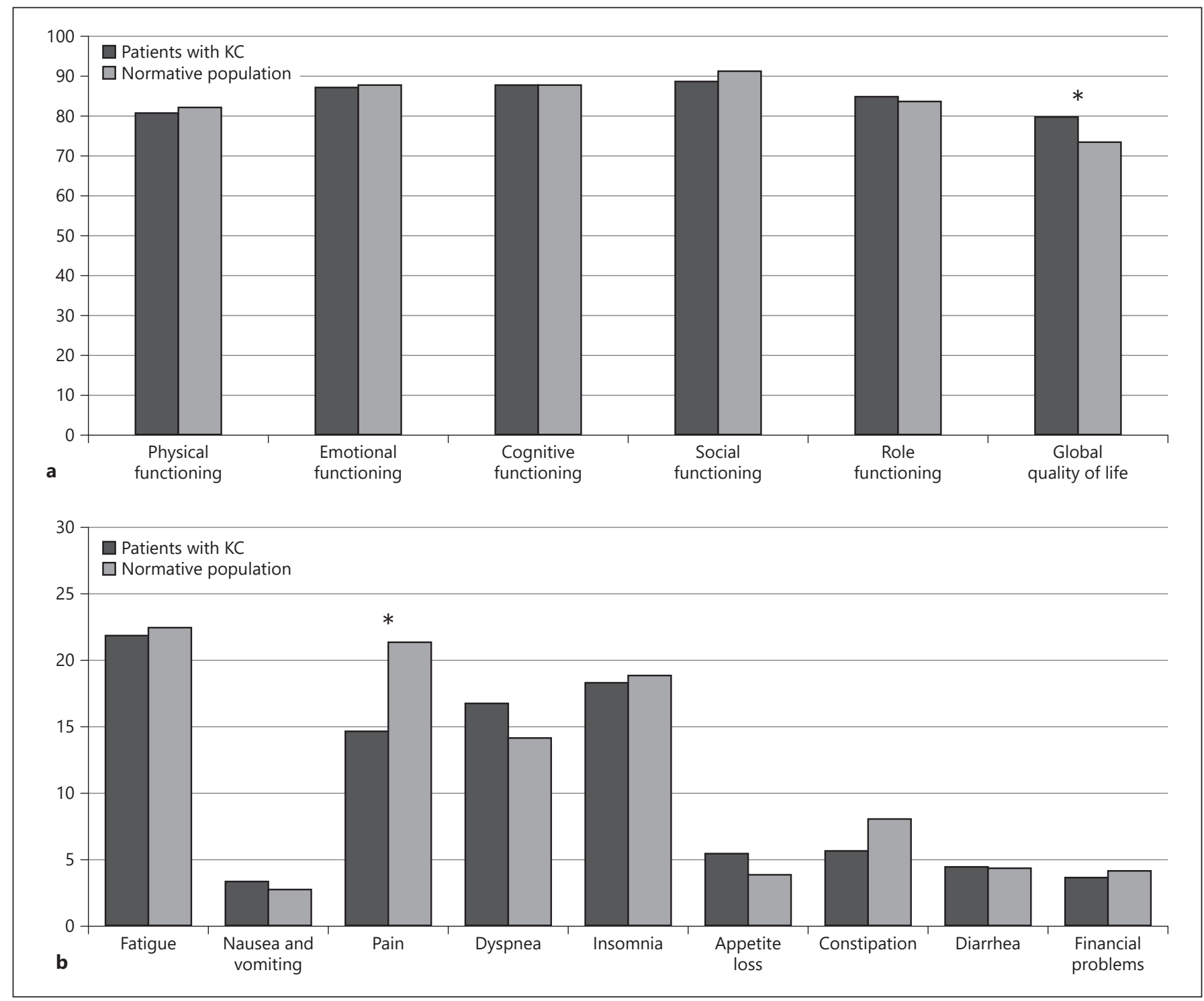

Fig. 3. Differences on EORTC QLQ-C30 mean functioning and global quality of life (a) and symptom scores (b) between patients with $\mathrm{KC}(n=215)$ and an age- and sex-matched normative population $(n=255) .{ }^{*} p<0.05$ and small clinically important difference. Note: a higher score on functioning scores implies a better

ance compared to patients who had only one skin cancer. Previous research showed that potential disfigurement and scarring is a concern for many patients $[11,12,36]$, especially multiple scars from multiple skin cancers.

Approximately half of the patients with $\mathrm{KC}$ rated their general satisfaction with care as "very good" or "excellent". High cure rates of both excision and radiotherapy $(>90 \%)$ might therefore be an explanation for high satisfaction scores [37]. health-related quality of life, whereas higher symptom scores refer to more symptoms. EORTC QLQ-C30, European Organisation for Research and Treatment of Cancer Quality of Life Questionnaire Core 30.

The current study has some limitations, such as the small sample size, which may limit the statistical significance of our findings. The sample size is especially small for patients treated with Mohs' micrographic surgery. At the time the patients included in this study were treated, the benefits of Mohs' micrographic surgery in the treatment of BCC and SCC had not yet been sufficiently demonstrated [38, 39]. Therefore, Mohs' micrographic surgery was not yet a standard of treatment for $\mathrm{KC}$ and as a 


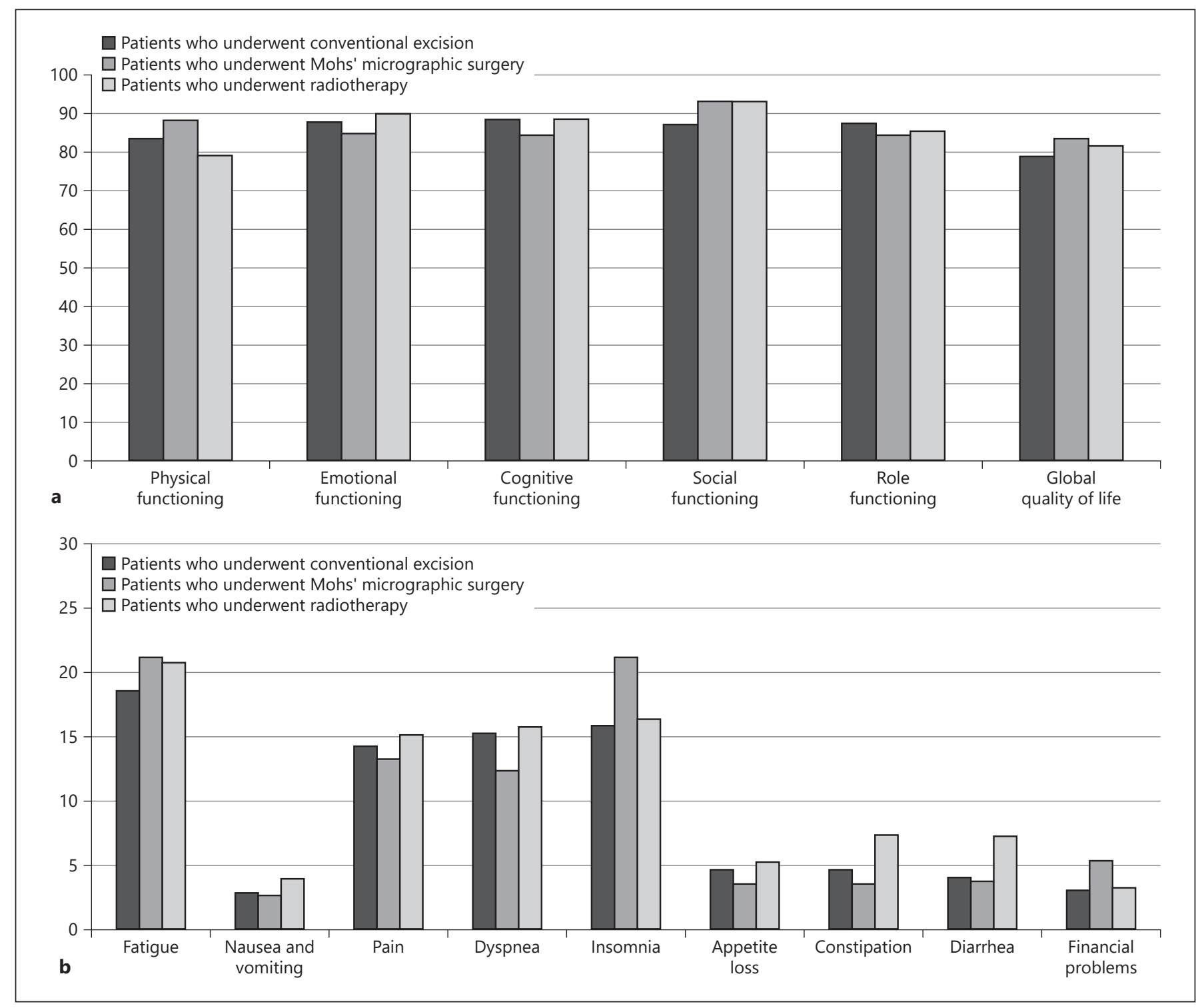

Fig. 4. Differences on EORTC QLQ-C30 mean functioning and global quality of life (a) and symptom scores (b) among patients with KC who underwent conventional excision $(n=106)$, Mohs' micrographic surgery $(n=19)$, or radiotherapy $(n=55)$. Note: a

result was used less frequently. The availability of Mohs' micrographic surgery in the NCR Eindhoven area has increased since 2014. The study should be replicated with a larger sample of KC patients to get more conclusive results. In addition, we did not have detailed information on radiotherapy schedules of $\mathrm{KC}$. Therefore, we are not aware whether the frequency of radiotherapy appointments has an impact on HRQoL and satisfaction with care. Furthermore, we did not have detailed information on nonresponding patients. Previous research reported

HRQoL among Patients with $\mathrm{KC}$ in the Head and Neck Area higher score on functioning scores implies a better health-related quality of life, whereas higher symptom scores refer to more symptoms. EORTC QLQ-C30, European Organisation for Research and Treatment of Cancer Quality of Life Questionnaire Core 30.

that patients not participating in observational patientreported outcome research may systematically have lower HRQoL scores compared to participants [40]. Therefore, observed outcomes might represent the healthier patient with better outcomes.

In conclusion, despite the cross-sectional design of this study, this population-based study gives an overview of the HRQoL that patients with KC experience after their disease and treatment. The impact of $\mathrm{KC}$ and its treatment seems relatively low and more positive than nega- 
Table 3. Differences among patients treated with radiotherapy, conventional excision, and Mohs' micrographic surgery on mean BaSQoL and EORTC IN-PATSAT32 scores and cosmetic results, adjusted for age

\begin{tabular}{|c|c|c|c|c|}
\hline & $\begin{array}{l}\text { Conventional } \\
\text { excision } \\
(n=106)\end{array}$ & $\begin{array}{l}\text { Mohs' } \\
\text { micrographic } \\
\text { surgery, }(n=19)\end{array}$ & $\begin{array}{l}\text { Radiotherapy } \\
(n=55)\end{array}$ & $p$ value \\
\hline \multicolumn{5}{|l|}{$\operatorname{BaSQoL}(0-3)^{1}$} \\
\hline Behavior & $0.7 \pm 0.7$ & $0.5 \pm 0.5$ & $0.6 \pm 0.7$ & 0.27 \\
\hline Diagnosis and treatment & $0.9 \pm 0.7$ & $1.0 \pm 1.0$ & $1.1 \pm 0.7$ & 0.39 \\
\hline Worries & $0.7 \pm 0.6$ & $0.7 \pm 0.7$ & $0.9 \pm 0.7$ & 0.44 \\
\hline Appearance & $0.3 \pm 0.5$ & $0.2 \pm 0.5$ & $0.3 \pm 0.4$ & 0.19 \\
\hline Other people & $0.7 \pm 0.7$ & $0.5 \pm 0.6$ & $0.6 \pm 0.7$ & 0.28 \\
\hline \multicolumn{5}{|l|}{ EORTC IN-PATSAT32 $(0-100)^{2}$} \\
\hline Doctors' technical skills & $65.4 \pm 19.4$ & $68.9 \pm 14.4$ & $66.6 \pm 22.0$ & 0.77 \\
\hline Doctors' interpersonal skills & $58.2 \pm 22.2$ & $67.1 \pm 20.1$ & $63.0 \pm 22.9$ & 0.19 \\
\hline Doctors' information provision & $64.5 \pm 21.4$ & $71.9 \pm 22.1$ & $69.3 \pm 22.0$ & 0.24 \\
\hline Doctors' availability & $55.5 \pm 24.3$ & $65.3 \pm 19.0$ & $59.7 \pm 25.2$ & 0.23 \\
\hline \multicolumn{5}{|l|}{ Other hospital staff interpersonal } \\
\hline skills and information provision & $66.9 \pm 20.0$ & $64.5 \pm 20.9$ & $73.6 \pm 22.9$ & 0.12 \\
\hline Exchange of information between caregivers & $56.1 \pm 21.2$ & $53.9 \pm 28.0$ & $58.8 \pm 21.7$ & 0.66 \\
\hline Waiting time & $61.4 \pm 18.2$ & $54.6 \pm 25.4$ & $64.9 \pm 22.6$ & 0.17 \\
\hline Hospital access & $60.5 \pm 18.3$ & $64.5 \pm 21.4$ & $66.6 \pm 23.2$ & 0.20 \\
\hline Hospital comfort/cleanness & $62.9 \pm 19.2$ & $68.4 \pm 18.3$ & $72.1 \pm 23.6$ & 0.03 \\
\hline General satisfaction & $64.4 \pm 19.6$ & $68.1 \pm 18.8$ & $68.8 \pm 21.6$ & 0.43 \\
\hline Cosmetic results $(0-10)^{3}$ & $7.9 \pm 1.5$ & $7.8 \pm 1.5$ & $8.5 \pm 1.1$ & 0.06 \\
\hline
\end{tabular}

tive as patients reported better HRQoL compared to an age- and sex-matched normative population, probably due to adaptation. No statistically significant differences between treatment types were found concerning HRQoL, patient satisfaction, and cosmetic results. This information could be used by healthcare professionals involved in $\mathrm{KC}$ care to improve patients' knowledge about different aspects of the disease as patient's preference is an important factor for treatment choice.

\section{Key Message}

Patients with KC reported better HRQoL than an age- and sexmatched normative population.

\section{Acknowledgments}

We thank all patients and their doctors for their participation in the study. Special thanks go to Dr. M. van Bommel for independent advice and answering questions of patients invited to participate. Specialists in the following hospitals provided cooperation:
Catharina Hospital, Eindhoven; Elisabeth-TweeSteden Hospital, Tilburg; DermaPark, Uden; and Dr. Bernard Verbeeten Institute, Tilburg.

\section{Statement of Ethics}

Patients gave their written informed consent. The study protocol was approved by a Medical Ethical Research Committee on human research.

\section{Disclosure Statement}

The authors have no conflicts of interest to declare.

\section{Funding Sources}

This study was supported by the Applied Radiotherapeutic Research Foundation (Stichting Toegepast Radiotherapeutisch Onderzoek), Mierlo, The Netherlands. The study funder had no role in the design of the study, writing the manuscript, or collection, management, analysis, and interpretation of data. 


\section{Author Contributions}

L.P.J.A. was responsible for patient recruitment, data collection, data analysis, and drafting the manuscript. R.W.-S. was a major contributor in writing the manuscript and was also responsible for data collection. M.L.M.L. was a major contributor in writing the manuscript, was responsible for data collection, and was involved in the development of the idea. K.-P.R.,
M.R.T.M.T., and L.J.S. were responsible for data collection and revised the manuscript critically for important intellectual content. M.J.A. was involved in the development of the idea and revised the manuscript critically for important intellectual content. S.O. revised the manuscript critically for important intellectual content. M.W.J.L. was a major contributor in writing the manuscript and supervised this study. All authors read and approved the final manuscript.

\section{References}

1 Kim RH, Armstrong AW. Nonmelanoma skin cancer. Dermatol Clin. 2012 Jan;30(1):125-39.

2 Dubas LE, Ingraffea A. Nonmelanoma skin cancer. Facial Plast Surg Clin North Am. 2013 Feb;21(1):43-53

3 Albert MR, Weinstock MA. Keratinocyte carcinoma. CA Cancer J Clin. 2003 Sep-Oct; 53(5):292-302.

4 Griffin LL, Ali FR, Lear JT. Non-melanoma skin cancer. Clin Med (Lond). 2016 Feb;16(1): $62-5$.

5 Lomas A, Leonardi-Bee J, Bath-Hextall F. A systematic review of worldwide incidence of nonmelanoma skin cancer. Br J Dermatol. 2012 May;166(5):1069-80.

6 de Vries E, Louwman M, Bastiaens M, de Gruijl F, Coebergh JW. Rapid and continuous increases in incidence rates of basal cell carcinoma in the southeast Netherlands since 1973. J Invest Dermatol. 2004 Oct;123(4): 634-8.

7 Smith V, Walton S. Treatment of facial Basal cell carcinoma: a review. J Skin Cancer. 2011; 2011:380371.

8 Rhee JS, Matthews BA, Neuburg M, Burzynski M, Nattinger AB. Creation of a quality of life instrument for nonmelanoma skin cancer patients. Laryngoscope. 2005 Jul; 115(7): $1178-85$.

9 Jennings L, Schmults CD. Management of high-risk cutaneous squamous cell carcinoma. J Clin Aesthet Dermatol. 2010 Apr;3(4): 39-48.

10 Fleming ID, Amonette R, Monaghan T, Fleming MD. Principles of management of basal and squamous cell carcinoma of the skin. Cancer. 1995 Jan;75(2 Suppl):699-704.

11 Garcovich S, Colloca G, Sollena P, Andrea B, Balducci L, Cho WC, et al. Skin Cancer Epidemics in the Elderly as An Emerging Issue in Geriatric Oncology. Aging Dis. 2017 Oct;8(5) 643-61.

12 Radiotis G, Roberts N, Czajkowska Z, Khanna M, Körner A. Nonmelanoma skin cancer: disease-specific quality-of-life concerns and distress. Oncol Nurs Forum. 2014 Jan;41(1):5765.

13 Chren MM, Sahay AP, Bertenthal DS, Sen S, Landefeld CS. Quality-of-life outcomes of treatments for cutaneous basal cell carcinoma and squamous cell carcinoma. J Invest Dermatol. 2007 Jun;127(6):1351-7.
14 Waalboer-Spuij R, Hollestein LM, Timman $\mathrm{R}$, van de Poll-Franse LV, Nijsten TE. Development and Validation of the Basal and Squamous Cell Carcinoma Quality of Life. (BaSQoL) Questionnaire. Acta Derm Venereol. 2018 Feb;98(2):234-9.

15 Bottomley A. The cancer patient and quality of life. Oncologist. 2002;7(2):120-5.

16 Waalboer-Spuij R, Nijsten TE. A review on quality of life in keratinocyte carcinoma patients. G Ital Dermatol Venereol. 2013 Jun; 148(3):249-54.

17 Rhee JS, Matthews BA, Neuburg M, Smith TL, Burzynski M, Nattinger AB. Quality of life and sun-protective behavior in patients with skin cancer. Arch Otolaryngol Head Neck Surg. 2004 Feb;130(2):141-6.

18 van Egmond S, Wakkee M, Droger M, Bastiaens MT, van Rengen A, de Roos KP, et al. Needs and preferences of patients regarding basal cell carcinoma and cutaneous squamous cell carcinoma care: a qualitative focus group study. Br J Dermatol. 2019 Jan;180(1):122-9.

19 Waalboer-Spuij R, Holterhues C, van Hattem S, Schuttelaar ML, Gaastra MT, Kuijpers DI, et al. Patient Perception of Imiquimod Treatment for Actinic Keratosis and Superficial Basal Cell Carcinoma in 202 Patients. Dermatology. 2015;231(1):56-62.

20 Magin P. Patient preferences and patient-centredness in skin cancer care: implications for clinicians and patient management. Br J Dermatol. 2019 Jan;180(1):22-3.

21 Cartee TV, Alam M, Armbrecht ES, Behera A Lawrence N, Bordeaux JS, et al. Patient-Centered Outcomes for Skin Cancer Management: Utilization of a Patient Delphi Process to Identify Important Treatment Themes. Dermatol Surg. 2019 Feb;45(2):246-53.

22 Bath-Hextall F, Nalubega S, Evans C. The needs and experiences of patients with skin cancer: a qualitative systematic review with metasynthesis. Br J Dermatol. 2017 Sep; 177(3):666-87.

23 Waalboer-Spuij R, Hollestein LM, van de Poll-Franse LV, Nijsten TE. Histological diagnosis of basal cell carcinoma is not associated with life expectancy in elderly Dutch people: a population-based cohort study. Br J Dermatol. 2017 Oct;177(4):e88-9.

24 Aaronson NK, Ahmedzai S, Bergman B, Bullinger M, Cull A, Duez NJ, et al. The European
Organization for Research and Treatment of Cancer QLQ-C30: a quality-of-life instrument for use in international clinical trials in oncology. J Natl Cancer Inst. 1993 Mar;85(5): 365-76.

25 Brédart A, Bottomley A, Blazeby JM, Conroy T, Coens C, D'Haese S, et al.; European Organisation for Research and Treatment of Cancer Quality of Life Group and Quality of Life Unit. An international prospective study of the EORTC cancer in-patient satisfaction with care measure (EORTC IN-PATSAT32). Eur J Cancer. 2005 Sep;41(14):2120-31.

26 Sangha O, Stucki G, Liang MH, Fossel AH, Katz JN. The Self-Administered Comorbidity Questionnaire: a new method to assess comorbidity for clinical and health services research. Arthritis Rheum. 2003 Apr;49(2): 156-63.

27 van de Poll-Franse LV, Horevoorts N, van Eenbergen M, Denollet J, Roukema JA, Aaronson NK, et al.; Profiles Registry Group. The Patient Reported Outcomes Following Initial treatment and Long term Evaluation of Survivorship registry: scope, rationale and design of an infrastructure for the study of physical and psychosocial outcomes in cancer survivorship cohorts. Eur J Cancer. 2011 Sep;47(14):218894.

28 van de Poll-Franse LV, Mols F, Gundy CM, Creutzberg CL, Nout RA, Verdonck-de Leeuw IM, et al. Normative data for the EORTC QLQ-C30 and EORTC-sexuality items in the general Dutch population. Eur J Cancer. 2011 Mar;47(5):667-75.

29 Cocks K, King MT, Velikova G, Martyn StJames M, Fayers PM, Brown JM. Evidencebased guidelines for determination of sample size and interpretation of the European Organisation for the Research and Treatment of Cancer Quality of Life Questionnaire Core 30. J Clin Oncol. 2011 Jan;29(1):89-96.

30 Joly F, Héron JF, Kalusinski L, Bottet P, Brune D, Allouache N, et al. Quality of life in longterm survivors of testicular cancer: a population-based case-control study. J Clin Oncol. 2002 Jan;20(1):73-80.

31 Ganz PA, Desmond KA, Leedham B, Rowland JH, Meyerowitz BE, Belin TR. Quality of life in long-term, disease-free survivors of breast cancer: a follow-up study. J Natl Cancer Inst. 2002 Jan;94(1):39-49.
HRQoL among Patients with KC in the Head and Neck Area
Dermatology 2020;236:133-142 DOI: $10.1159 / 000502033$ 
32 de Vries M, Hoekstra HJ, Hoekstra-Weebers JE. Quality of life after axillary or groin sentinel lymph node biopsy, with or without completion lymph node dissection, in patients with cutaneous melanoma. Ann Surg Oncol. 2009 Oct;16(10):2840-7.

33 Schwartz CE, Sprangers MA. Methodological approaches for assessing response shift in longitudinal health-related quality-of-life research. Soc Sci Med. 1999 Jun;48(11):153148.

34 Rong Y, Zuo L, Shang L, Bazan JG. Radiotherapy treatment for nonmelanoma skin cancer. Expert Rev Anticancer Ther. 2015;15(7):76576.

35 Skiveren J, Mikkelsen MR, Daugbjerg H, Wulf HC. Skin reactions and quality of life af- ter x-ray therapy of Basal cell carcinoma. J Skin Cancer. 2012;2012:825095.

36 Bath-Hextall F, Jenkinson C, Kumar A, Leonardi-Bee J, Perkins W, Cox K, et al. Longitudinal, mixed method study to look at the experiences and knowledge of non melanoma skin cancer from diagnosis to one year. BMC Dermatol. 2013 Oct;13(1):13.

37 Connolly KL, Nehal KS, Disa JJ. EvidenceBased Medicine: Cutaneous Facial Malignancies: Nonmelanoma Skin Cancer. Plast Reconstr Surg. 2017 Jan;139(1):181e-90e.

38 van Lee CB, Roorda BM, Wakkee M, Voorham Q, Mooyaart AL, de Vijlder HC, et al. Recurrence rates of cutaneous squamous cell carcinoma of the head and neck after Mohs micrographic surgery vs. standard excision: a retrospective cohort study. $\mathrm{Br} J$ Dermatol. 2019 Aug;181(2):338-43.

39 Flohil SC, van Dorst AM, Nijsten T, Martino Neumann HA, Munte K. Mohs micrographic surgery for basal cell carcinomas: appropriateness of 'Rotterdam' criteria and predictive factors for three or more stages. J Eur Acad Dermatol Venereol. 2013 Oct;27(10):122835.

40 de Rooij BH, Ezendam NP, Mols F, Vissers PA, Thong MS, Vlooswijk CC, et al. Cancer survivors not participating in observational patient-reported outcome studies have a lower survival compared to participants: the population-based PROFILES registry. Qual Life Res. 2018 Dec;27(12):331324. 